\title{
Brachialis muscle tendon insertion avulsion fracture in a 6-year-old child
}

\author{
Sebastien Crosswell, Chibuogwu Anthonia Mbah, Abid Hussain, Robert Turner
}

T\&O, PRH Telford, Telford, Shropshire, UK

\section{Correspondence to} Dr Sebastien Crosswell, sebastien.crosswell@doctors. org.uk
CrossMark

To cite: Crosswell $S$ Mbah CA, Hussain A, et al. BMJ Case Rep Published online: [please include Day Month Year] doi:10.1136/ bcr-2013-202420

\section{DESCRIPTION}

A 6-year-old boy, who fell while playing at school, presented to the fracture clinic with a suspected right distal radius fracture. On examination, the child was tender over the dorsal aspect of the distal radius and also had pain and stiffness around the elbow joint with a lack of the last $25^{\circ}$ of elbow flexion. An acute haemarthrosis was also suspected at presentation. Plain anteroposterior (AP) and lateral radiographs of the elbow joint revealed an abnormal calcification superimposed on the anterior aspect of the coronoid process (figure $1 \mathrm{~A}, \mathrm{~B}$ ), which had not been visualised on plain radiographs in A\&E.

A CT scan, as suggested by the radiologists, revealed a $3 \mathrm{~cm}$ avulsion fracture of the anterior
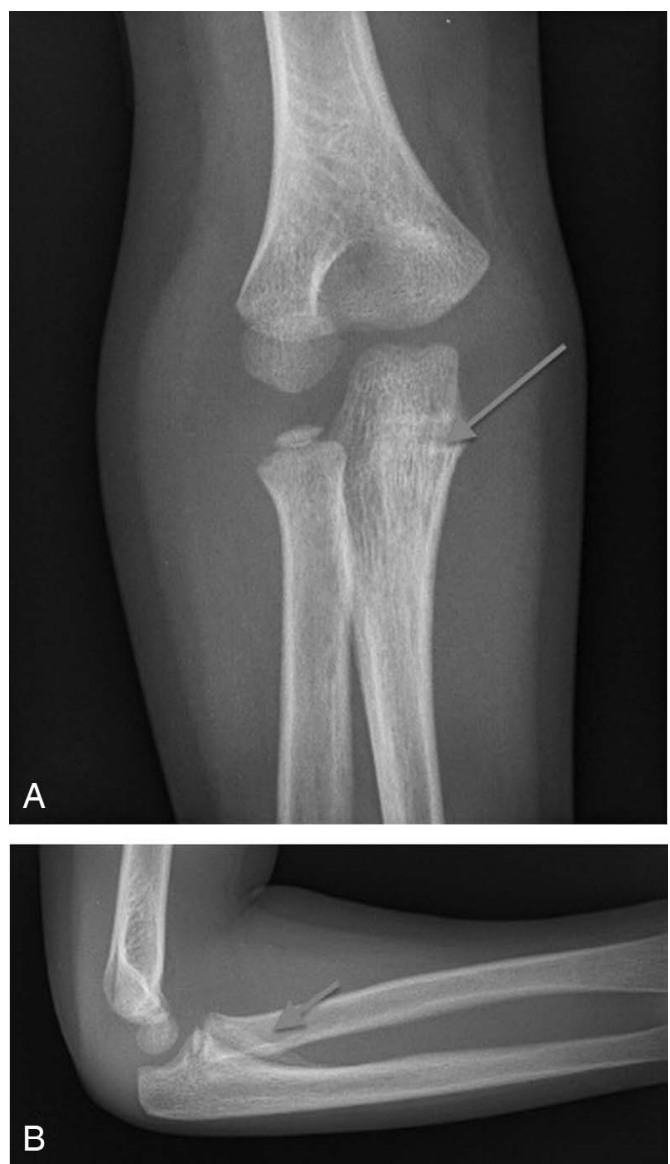

Figure 1 (A) Anteroposterior plain radiograph of the right elbow joint showing a possible cortical breech of proximal ulna surface. (B) Lateral plain radiograph of the right elbow joint showing abnormal calcification on anterior aspect of proximal ulna.

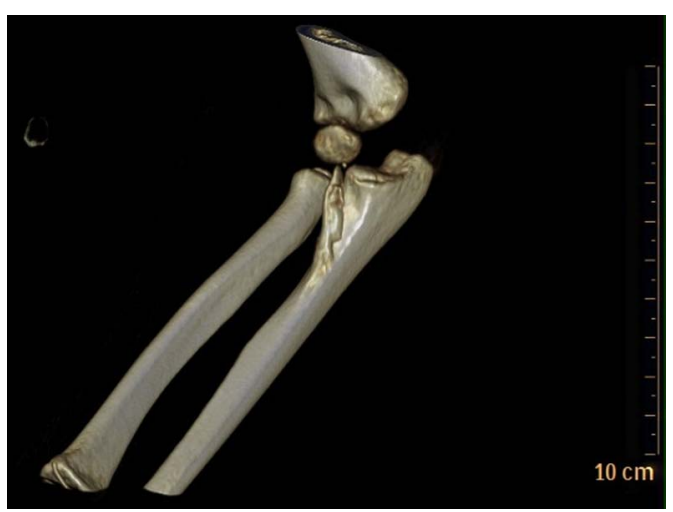

Figure 2 CT three-dimensional reconstruction of the right elbow showing a $3 \mathrm{~cm}$ avulsion fracture of the anterior surface of the proximal ulna.

surface of the proximal ulna, which corresponded to the calcification seen on lateral plain radiographs (figure 1B) and was thought to be an avulsion fracture of the insertion of brachialis muscle (figure 2). The child was immobilised at the wrist and elbow for 3 weeks with a plaster cast and repeat radiographs were performed to monitor the migration of the avulsion fragment.

The brachialis muscle insertion comprises two distinct tendons originating from the deep and superficial heads of the brachialis muscle inserting into the ulna tuberosity and coronoid process. Studies investigating elbow trauma using ultrasound have shown it to commonly be the deep head that is responsible for avulsion injuries caused by a sudden unexpected movement at the elbow joint. ${ }^{1}$

There have been cases of coronoid process fractures due to avulsion by the medial collateral ligaments, biceps tendon insertion and avulsion fracture in combination with other injuries, for example, olecranon fractures or elbow dislocations. ${ }^{2}{ }^{3}$ In this case, a 6 -year-old child sustaining a brachialis avulsion fracture of this extent following low-energy trauma has not been reported in the literature. Initial concerns for this child were slow resolution of stiffness and poor functional recovery at the elbow joint as reported in similar patients. $^{2}$

Despite our concerns at the 3-month follow-up, the child had full range of movement in his right elbow with no tenderness and was undertaking normal activities at school; therefore, conservative management was continued and the child was followed up at six monthly intervals. 


\section{Learning points}

- This case emphasises the importance of careful clinical and radiological examination in treating paediatric elbow injuries.

- Surgery should be avoided in these types of paediatric elbow injuries if they are asymptomatic and have no functional deficit.

- Regular follow-ups on these types of injuries in children are necessary to monitor the risk of ectopic ossification.
Contributors SC wrote the case report, assisted by CAM. AH obtained the patient consent and RT supervised the case report.

Competing interests None.

Patient consent Obtained.

Provenance and peer review Not commissioned; externally peer reviewed.

\section{REFERENCES}

1 Tagliafico A, Michaud J, Perez MM, et al. Ultrasound of distal brachialis tendon attachment: normal and abnormal findings. Br J Radiol 2013;86:20130004.

2 Gadgil A, Roach R, Neal N, et al. Isolated avulsion fracture of the coronoid process requiring open reduction in a paediatric patient: a case report. Acta Orthop Belg 2002;68:396-8.

3 Kowtharapu DN, Thabet AM, Holmes L Jr, et al. Osteochondral flap avulsion fracture in a child with forearm compartment syndrome. Orthopaedics 2008;31:805.

Copyright 2014 BMJ Publishing Group. All rights reserved. For permission to reuse any of this content visit http://group.bmj.com/group/rights-licensing/permissions.

BMJ Case Report Fellows may re-use this article for personal use and teaching without any further permission.

Become a Fellow of BMJ Case Reports today and you can:

- Submit as many cases as you like

- Enjoy fast sympathetic peer review and rapid publication of accepted articles

- Access all the published articles

- Re-use any of the published material for personal use and teaching without further permission

For information on Institutional Fellowships contact consortiasales@bmjgroup.com

Visit casereports.bmj.com for more articles like this and to become a Fellow 